\title{
General practitioners' attitudes to professional reaccreditation
}

\author{
Stephen H H Sylvester
}

\author{
Abstract \\ Objective-To determine the views of general \\ practitioners about professional reaccreditation. \\ Design-Postal questionnaire. \\ Subjects-All 278 general practitioner principals \\ working in Cleveland.
}

Main outcome measures-General practitioner characteristics; attitudes to reaccreditation; and views on the development, conduct, content, and format of reaccreditation.

Results-210 out of $278(76 \%)$ general practitioners responded to the questionnaire. $128(61 \%)$ agreed that general practitioners should undergo reaccreditation. $149(72 \%)$ thought the General Medical Services Committee and local medical committees were appropriate bodies to lead its development. 120 respondents suggested that reaccreditation should be carried out by assessors appointed by the doctor's own local medical committee. The most favoured interval between reaccreditation episodes was 10 or more years. 152 doctors thought that doctors who failed reaccreditation should be advised on education and reassessed soon afterwards. Clinical knowledge $(82 \%)$, clinical skill $(82 \%)$, prescribing practices $(67 \%)$, standards of medical record keeping $(60 \%)$, and consultation behaviour $(58 \%)$ were the most popular subjects for scrutiny. $138(67 \%)$ respondents felt that reaccreditation should be part of continuing medical eduction.

Conclusion-Most general practitioners support professional reaccreditation. They believe the process should be led by the profession, be educational, and take account of a range of professional activities.
Tennant Street Surgery, Stockton on Tees TS18 2AT

Stephen H H Sylvester, general practitioner tutor

$B M F$ 1993;307:912-4

\section{Introduction}

In 1992 the General Medical Services Committee of the British Medical Association commissioned a national survey of general practitioners" to "provide every general practitioner in the country with an opportunity to record his/her view on the current state of general practice and what changes, if any, they would like to see in the future." The survey raised the

TABLE I-Respondents' attitudes to reaccreditation. Results are numbers (and percentages) of 210 respondents

\begin{tabular}{|c|c|c|c|}
\hline & Agree & $\begin{array}{l}\text { Neither agree } \\
\text { nor disagree }\end{array}$ & Disagree \\
\hline GPs should undergo reaccreditation during their practising careers & $128(61)$ & $31(15)$ & $51(24)$ \\
\hline $\begin{array}{l}\text { Attendance at PGEA approved events is sumcient evide } \\
\text { continuing competence to practise }\end{array}$ & $76(37)$ & $35(17)$ & $97(47)$ \\
\hline Reaccreditation will result in better doctors & $78(37)$ & $56(27)$ & $76(36)$ \\
\hline Reaccreditation will improve the quality of patient care & $80(38)$ & $61(29)$ & $69(33)$ \\
\hline $\begin{array}{l}\text { A reaccreditation system will help the state get better value for money from } \\
\text { doctors }(n=207)\end{array}$ & $34(16)$ & $60(29)$ & $113(55)$ \\
\hline Reaccreditation will be used to identify bad doctors & $89(42)$ & $56(27)$ & $65(31)$ \\
\hline $\begin{array}{l}\text { Reaccreditation is a public relations gimmick } \\
\text { A system of reaccreditation will result in the loss of the GP's independent }\end{array}$ & $90(43)$ & $41(20)$ & $79(38)$ \\
\hline contractor status & $47(22)$ & $65(31)$ & $98(47)$ \\
\hline I worry that reaccreditation could result in the loss of my livelihood & $61(29)$ & $36(17)$ & $113(54)$ \\
\hline It concerns me that reaccreditation may expose my inadequacies & $65(31)$ & $42(20)$ & $103(49)$ \\
\hline Only GPs should be involved in reaccrediting other GPs & $151(72)$ & $28(13)$ & $31(15)$ \\
\hline
\end{tabular}

PGEA= postgraduate education allowance. issue of professional reaccreditation, which it defined as "a system of assessing a GP's competence to practice, at regular intervals during his or her career." Sixty five per cent of general practitioners responding to the survey disagreed with the statement that once a general practitioner had acquired a basic level of competence no further form of reappraisal was necessary during the rest of a professional life, and $42 \%$ agreed that a system of reaccreditation in general practice was long overdue.

Reaccreditation or recertification of doctors is not new. Since 1976 the American Board of Family Practice has issued time limited certificates to family physicians, demanding recertification by assessment. Since then systems of reaccreditation have developed in Australia, New Zealand, and the Netherlands. In the United Kingdom, general practices wishing to train general practitioners are accredited and reaccredited by means of a practice visit from a team of assessors. In 1989 the Royal College of General Practitioners introduced fellowship by assessment-an example of voluntary and stringent reaccreditation. ${ }^{2}$ In 1992 the Royal College of Obstetricians and Gynaecologists recommended compulsory reaccreditation for specialists based on continuing medical education. ${ }^{3}$

Progress towards compulsory reaccreditation for general practitioners is inevitable, but questions remain about how doctors should be reaccredited and who should be involved in developing and applying the system. This study aimed to test the results of the General Medical Services Committee's survey and to determine general practitioners' views on the development and application of reaccreditation.

\section{Method}

A postal questionnaire was sent to all 278 general practitioner principals on the medical list of the Cleveland Family Health Services Authority in January 1993. The questions were derived through a series of structured interviews with a selection of general practitioners in Cleveland. General practitioners involved in education and political representation were then invited to check that no major options had been omitted. The structure and wording of the questionnaire was examined and criticised by a researcher experienced in questionnaire design.

Statistical analysis was carried out by using the $\chi^{2}$ test (with Yates's correction where appropriate) with a $95 \%$ confidence interval $\left(\chi^{2} \geqslant 5 \cdot 024\right)$.

\section{Results}

Of the 278 questionnaires posted, 210 were returned completed-a response rate of $75 \cdot 5 \%$.

Doctors' attitudes to reaccreditation-The responses to the 11 attitudinal questions asked in the survey are displayed in table I. Although the questionnaire had a five point scale, categories have been combined in table 
I into a three point scale. Only 19 out of $118(16 \%)$ doctors who were members of the Royal College of General Practitioners were opposed to reaccreditation while 32 out of $92(35 \%)$ who had never been College members opposed it $\left(\chi^{2}=5 \cdot 17, p=0 \cdot 0230\right)$. Likewise, only two out of $56(4 \%)$ doctors from training practices opposed reaccreditation compared with 49 out of 154 $(32 \%)$ doctors from non-training practices $\left(\chi^{2}=11 \cdot 00\right.$, $\mathrm{p}=0.0009$ ). The sex of the doctor, practice size, and the number of years the doctor had been in practice made no difference to the view on the need for reaccreditation. The view that attendance at courses approved for the postgraduate education allowance was sufficient evidence of continuing competence to practise was held by 53 out of $91(58 \%)$ non-college members but only 23 out of $117(20 \%)$ college members $\left(X^{2}=14.02, \mathrm{p}=0.0002\right)$.

Who should lead the development of reaccreditation?Table II displays the respondents' views on which bodies should lead the development of reaccreditation. Support for the General Medical Services Committee or local medical committees was not affected by the doctor's sex, college membership, practice size, training status, or number of years in practice. Seventy five out of $117(64 \%)$ college members favoured the college as a leader of reaccreditation compared with only 28 out of $90(31 \cdot 1 \%)$ non-college members $\left(\chi^{2}=7 \cdot 07\right.$, $\mathrm{p}=0.0078$ ).

Who should carry out reaccreditation?-Support for assessors appointed by the doctor's own local medical committee was not affected by the doctor's sex, college membership, practice size, training status, or number of years in practice (table II).

When should reaccreditation be carried out?Comparison of the responses of doctors who supported and opposed reaccreditation showed no significant difference as far as an interval of 10 or more years was concerned (table III). However, only two out of 45 (4\%) doctors opposed to reaccreditation favoured an interval of fewer than 10 years compared with 57 out of $128(45 \%)$ who favoured reaccreditation. Opponents of reaccreditation were significantly more likely than supporters to suggest professional misconduct (13/45 $v$ $7 / 128)$ or a breach of terms of service $(14 / 45 v 2 / 128)$ as appropriate triggers for reaccreditation.

What should happen to those who fail reaccreditation? -Altogether 202 respondents answered a question on what should happen to doctors who fail reaccreditation. One hundred and fifty two thought that such

TABLE II-Respondent's views on who should lead the development of reaccreditation and who should carry it out. Respondents could choose up to three options

\begin{tabular}{lc}
\hline & $\begin{array}{c}\text { No (\%) of } \\
\text { respondents (n-207) }\end{array}$ \\
\hline Who should lead? & \\
General Medical Services Committee/local medical & \\
committees & $149(72)$ \\
Royal College of General Practitioners & $103(50)$ \\
British Medical Association & $88(43)$ \\
General Medical Council & $87(42)$ \\
University departments of general practice & $48(23)$ \\
Family health services authorities & $38(18)$ \\
Department of Health & $8(4)$ \\
Who should carry out accreditation? & \\
Assessors appointed by the local medical & $120(58)$ \\
committee & $83(40)$ \\
Your partners or fellow GPs & $72(35)$ \\
Regional or associate advisers in general practice & \\
Assessors appointed by the General Medical & $50(24)$ \\
Council & $42(20)$ \\
General practitioner tutors & $38(18)$ \\
Assessors appointed by a different local medical & $35(17)$ \\
committee & $26(13)$ \\
General practice trainers & $19(9)$ \\
Independent medical advisor from the family & $16(8)$ \\
health services authority & $7(4)$ \\
Course organisers of vocational training & \\
Assessors appointed by the family health services & \\
authority & \\
Hospital consultants & \\
\hline
\end{tabular}

TABLE III-Respondent's views on when reaccreditation should be carried out

\begin{tabular}{lc}
\hline & $\begin{array}{c}\text { No (\%) of } \\
\text { respondents (n= 203) }\end{array}$ \\
\hline $\begin{array}{l}\text { Every ten or more years throughout a GP's career } \\
\text { Every five to nine years throughout a GP's career } \\
\text { When a doctor is found guilty of professional } \\
\text { misconduct by the GMC }\end{array}$ & $82(40)$ \\
$\begin{array}{l}\text { When a doctor is found to be in breech of his or her } \\
\text { terms of service by a service committee }\end{array}$ & $24(28)$ \\
$\begin{array}{l}\text { When a doctor becomes eligible for the first and } \\
\text { subsequent seniority payments }\end{array}$ & $22(11)$ \\
$\begin{array}{l}\text { More frequently than every five years throughout a } \\
\text { GP's career }\end{array}$ & $16(8)$ \\
\hline
\end{tabular}

TABLE IV-Respondent's views on what aspects of a GP's work should be scrutinised by reaccreditation. Any number of options could be selected

\begin{tabular}{lc}
\hline & $\begin{array}{c}\text { No }(\%) \text { of } \\
\text { respondents }(\mathrm{n}=209)\end{array}$ \\
\hline Clinical knowledge & $172(82)$ \\
Clinical skill & $171(82)$ \\
Prescribing practices & $139(67)$ \\
Standard of medical record keeping & $125(60)$ \\
Consultation behaviour & $121(58)$ \\
Patient satisfaction & $100(48)$ \\
Practice management & $89(43)$ \\
Workload & $86(41)$ \\
Quality of referral letters & $77(37)$ \\
Involvement in audit & $48(23)$ \\
Referral rates to hospitals & $41(20)$ \\
\hline
\end{tabular}

doctors should be advised to undertake appropriate education before being reassessed soon afterwards; 49 that they should be advised to undertake appropriate education (without reassessment), and one that they should be removed from the General Medical Council's specialist register. No one thought they should lose their licence to practice or receive lower practice allowances. The most popular choice (of education followed by reassessment) was not significantly affected by whether the responding doctor supported reaccreditation or not.

What aspects of performance should be scrutinised?Table IV lists aspects of a general practitioner's work which might be included in reaccreditation. Of 128 doctors in favour of reaccreditation $59(46 \%)$ included the quality of referral letters compared with only seven out of $50(14 \%)$ opponents of reaccreditation $\left(\chi^{2}=7 \cdot 27\right.$, $\mathrm{p}=0.007)$. Thirty eight out of $128(30 \%)$ supporters included involvement in medical audit compared with only four out of $50(8 \%)$ opponents $\left(\chi^{2}=5 \cdot 36\right.$, $\mathrm{p}=0.0206$ ). Choice of the remaining criteria was not significantly affected by whether the doctor supported reaccreditation or not.

What should be the format of reaccreditation?-Two hundred and five doctors indicated what they considered the most suitable format for reaccreditation. They could select any combination of five options presented. One hundred and thirty eight opted for reaccreditation as part of continuing medical education, 113 suggested a practice visit by a small team of people, 34 chose some form of written examination, 27 chose an oral examination, and 23 favoured simulated consultations using actors as patients. Choice of a practice visit as a suitable format was not significantly affected by the training status of the responding doctor's practice.

\section{Discussion}

The $75.5 \%$ response rate achieved in this survey means that the results may be considered representative of the views of the general practitioners in Cleveland. The sample is too small to permit a confident extrapolation of these beyond Cleveland. Nevertheless, given the strong similarities between Cleveland general practitioners and general prac- 
titioners in the United Kingdom as a whole, ${ }^{4}$ I believe that these results probably do reflect wider general practice opinion. The impression from the General Medical Services Committee survey that most general practitioners favour some form of reaccreditation is borne out in this study.

\section{DOCTORS' BELIEFS AND ATTITUDES}

Differences in doctors' attitudes to reaccreditation may have more to do with their affiliation to the Royal College of General Practitioners and the training status of their practice than with their practice size or length of service. In this study, doctors near retirement or who were singlehanded were as likely to support reaccreditation as their younger or group practice colleagues. One reason for the greater willingness of college members and doctors in training practices to accept reaccreditation might be that both these groups have had experience of being assessed as general practitioners. A more systematic assessment of vocational training applied nationally might result in greater professional confidence about reaccreditation. The strong support among doctors for peer review as a vital element in reaccreditation needs to be reflected in the way it is developed and implemented. Doctors may be ambivalent about the value of reaccreditation, but their responses also suggest that they are not afraid of it.

\section{DEVELOPING AND CARRYING OUT REACCREDITATION}

Liaison between the General Medical Service Committee and the Royal College of General Practitioners in discussing reaccreditation ${ }^{5}$ would find favour with general practitioners. Despite suggestions that the negotiation of the 1990 general practitioner contract caused the profession to lose trust in the committee and college,${ }^{6}$ this study shows that general practitioners are willing to entrust these two bodies with the delicate issue of reaccreditation.

Doctors in Cleveland strongly believe reaccreditation should be an education exercise. Two thirds thought it ought to be part of continuing medical education and three quarters saw "failure" as a trigger for education before reassessment. Development and implementation of a system which emphasised the educational nature of reaccreditation would certainly find professional support.

A reaccreditation interval of 10 or more years would find widest acceptance, especially among those doctors opposing or unsure of reaccreditation. If the profession is to move ahead together then this longer interval, at least initially, would be more likely to help.

HOW SHOULD DOCTORS BE REACCREDITED?

The high ratings given to prescribing practices and consultation behaviour deserve mention. At present general practices are set indicative prescribing budgets which are monitored by and discussed with the independent medical adviser of the family health services authority. With some adaptation the present

\section{Practice implications}

- Demands for professional reaccreditation of all doctors, including general practitioners, are increasing

- There is broad based support for reaccreditation among general practitioners

- Doctors who have experience of assessment feel more confident about reaccreditation

- Reaccreditation should be led by the profession, embrace peer review, and be educational rather than punitive

- An interval of ten or more years between assessments has the greatest support among general practitioners

system of prescribing monitoring could become part of a reaccreditation process.

Observing and analysing a representative sample of every general practitioner's consultations would be costly in time, effort, and money. Unless there are sufficient resources to ensure that conclusions from an analysis of consultations are valid and that appropriate remedial training is available, this criterion of performance may be best excluded. Also, few general practitioners have experience of simulated consultations, though they are being developed as a tool of assessment in the Netherlands. ${ }^{7}$ Oral and written examinations have little support. Practice visits and continuing medical education are the favoured formats.

\section{Conclusions}

This survey has confirmed the overall acceptance of professional reaccreditation by general practitioners so long as it is educational rather than punitive and covers many different areas of activity. It is now up to general practitioners' leaders to develop a system that reflects these views.

This survey received financial support from the Cleveland primary care research panel. I also thank Dr Pali Hungin, Ms Sue Lydeard, Joanne Ling, Bernie Convery, and Hilda Flanagan for their advice and support.

1 General Medical Services Committee. Your choices for the futuure. A survey of $G P$ opinion. UK Report. London: GMSC, 1992.

2 Royal College of General Practitioners. Fellowship by assessment. London: RCGP 1990 (Occasional Paper 50).

3 Royal College of Obstetricians and Gynaecologists. Repor of the Working Party on Continuing Medical Education. London: RCOG, 1991 (Peel report).

4 General Medical Services Committee. Your choices for the future. Cleveland Report. London: GMSC, 1992.

5 Ormell C. Are GPs ready to take the test? Medeconomics 1992;March:63.

6 Little S. GPs accept the inevitable over periodic assessment. Pulse 1991, 27July:24.

7 Rethans J-J, Sturmans F, Drop R, van de Veleuten C. Assessment of the performance of general practitioners by the use of standardised (simulated) patients. Br f Gen Pract 1991;41:97-9.

(Accepted 12 August 1993) 